\title{
Актуальні діагностичні рішення клінічного завдання «Оцінка рівня йодного насичення організму»
}

М.І. Бобрик', В.М. Резніченко

${ }^{1}$ Національний медичний університет імені О.О. Богомольця

Державний заклад «Поліклініка № 2» Державного управління справами

Резюме. У статті наведено актуальні алгоритми ведення пацієнтів із йододефіцитом, у тому числі оптимальний комплекс лабораторної оцінки тиреоїдного статусу перед призначенням терапії - визначення рівнів ТТГ, вільн. Т (та вільн. Т рецептора ТТГ стимулюючих, за наявності додаткового утворення в ділянці щитоподібної залози - визначення рівнів паратгормону, кальцію іонізованого, 25-гідроксивітаміну D, кальцитоніну. Обгрунтовано необхідність ураховування інтерферуючих факторів, які впливають на результати досліджень (супутні стани у пацієнта, приймання препаратів, дотримання пацієнтом умов преаналітичного етапу), у тому числі можливість отримання хибних результатів, якщо пацієнт приймає препарати біотину та лабораторне дослідження проводилося за біотин-залежною методикою імуноаналізу.

ключові слова: йододефіцит, ТТГ, вільн. Т $4^{\prime}$ АТПО, антитіла до рецептора ТТГ стимулюючі, 25-гідроксивітамін D, Кальцитонін, інтерферуючі фактори, біотин.

Йододефіцит (ЙДЗ) є поширеною проблемою у світі та спричинює тяжкі наслідки для здоров’я популяції. Стан йододефіциту виявлено та підтверджено не лише в гірських регіонах, а й у прибережних, регіонах, де поширеність зоба є низькою, великих містах, високорозвинених країнах, регіонах, де вважалося, що дефіцит йоду усунений. Проведені 1997-2000 pр. відділом епідеміології ендокринних захворю-

* Адреса для листування (Correspondence): Національний медичний університет імені О.О. Богомольця, бульвар Тараса Шевченка, 13, м. Київ, 01601, Україна. E-mail: 100mib@rambler.ru

(с) М.І. Бобрик, В.М. Резніченко вань Інституту ендокринології та обміну речовин ім. В.П. Комісаренка вперше епідеміологічні дослідження з використанням стандартних критеріїв ВООЗ констатували наявність йодної недостатності слабкого, середнього й тяжкого ступенів на території практично всіх регіонів України [5, 6].

ЙДЗ викликає захворювання щитоподібної залози (ЩЗ), наслідком порушень тиреоїдного статусу є розлади, специфіка яких залежить від періоду життя, в якому ці захворювання проявляються: 
- у пренатальний період - спонтанні викидні, мертвонароджуваність, вроджені вади розвитку, перинатальна смертність;

- у новонароджених - вроджений гіпотиреоз, дитяча смертність, за вираженого дефіциту йоду - ендемічний неврологічний кретинізм;

- у дітей і підлітків - ендемічний зоб, гіпотиреоз, порушення розумового та фізичного розвитку, порушення формування репродуктивної системи;

- у дорослих - ендемічний зоб, гіпотиреоз, зниження фізичної та інтелектуальної працездатності;

- у жінок дітородного віку - ендемічний зоб, анемія, неплідність, невиношування вагітності, передчасні пологи, ризик народження дитини з розумовою відсталістю [1-5].

$\mathrm{y}$ різних країнах на державному рівні впроваджуються програми профілактики та ліквідації ЙДЗ. Основними координаторами цих програм є відповідні національні комітети, координаційні ради, ВООЗ, ЮНICEФ, ICCIDD, Україну також включено до Програми ЮНІСЕФ і Міжнародної ради ВООЗ із контролю йодної недостатності [5]. Натомість заходи, що їх вживають, є недостатньо ефективними:

- скринінг ЙДЗ у регіонах України нерегулярний;

- якість інформування населення про важливість проблеми ЙДЗ потребує поліпшення;

- домогосподарства, що користуються йодованою сіллю, становлять незначну частку;

- групова йодна профілактика шляхом регулярного тривалого вживання медикаментозних препаратів, що містять фіксовану фізіологічну дозу йоду, у групах найбільшого ризику розвитку ЙДЗ (діти, підлітки, вагітні та жінки, які годують) не є систематичною.

Оскільки вміст йоду в харчових продуктах і воді не забезпечує потреб організму, необхідним $є$ щоденне додаткове вживання йоду. Всесвітня організація охорони здоров'я встановила норми щоденного споживання йоду (ВООЗ, 2007): діти дошкільного віку (0-6 років) - 90 мкг; діти шкільного віку (6-12 років) - 120 мкг; підлітки (понад 12 років) і дорослі - 150 мкг; вагітні та жінки в період грудного вигодовування - 250 мкг. Йодна профілактика здійснюється шляхом регулярного тривалого вживання медикаментозних препаратів, що містять фіксовану фізіологічну дозу йоду: для дітей віком до 12 років - 50-100 мкг на день; для підлітків і дорослих - 100-200 мкг на день; під час вагітності та годування груддю -250 мкг на день.

Існують такі види йодної профілактики. Масова - збагачення йодом основних харчових продуктів, солі, хліба, води. Ефективна - якщо понад 90\% населення споживають йодовану сіль (на кожний кілограм солі додано 40 мг калію йодату). Індивідуальна - споживання продуктів із підвищеним вмістом йоду (морська риба, продукти моря). Групова профілактика здійснюється шляхом регулярного тривалого вживання медикаментозних препаратів, що містять фіксовану фізіологічну дозу йоду, у групах найбільшого ризику розвитку ЙДЗ (діти, підлітки, вагітні та жінки, які годують) препаратами йоду. Препарати калію йодиду містять добову фізіологічну дозу йоду, тому їх слід приймати щоденно, після їжі, запиваючи водою.

Критерії, які використовують із метою оцінки ступеня йодного дефіциту (ВООЗ/ЮНІСЕФ/ ICCIDD):

- частота зоба за даними пальпаторного обстеження та тиреомегалії за даними УЗД;

- медіана екскреції йоду із сечею;

- рівень тиреотропного гормону (ТТГ);

- рівень тиреоглобуліну в сироватці крові.

Медіана екскреції йоду із сечею:

$\leq 20$ мкг/л - споживання йоду вважають недостатнім, а дефіцит йоду - тяжким;

$\leq 20-49$ мкг/л - споживання йоду вважають недостатнім, а дефіцит йоду - помірним;

250-99 мкг/л - споживання йоду вважають недостатнім, а дефіцит йоду - легким;

$\geq 100$ мкг/л засвідчує відсутність дефіциту йоду в певній популяції. За медіани йодурії 100199 мкг/л споживання йоду вважають нормальним і забезпеченість йодом - оптимальною.

Слід враховувати, що критеріі, які використовують для оцінки ступеня йодного дефіциту, не є індивідуальними, застосовуються для епідеміологічних досліджень. Важливо, що не лише стан йододефіциту, а й надлишок йоду можуть призвести до небажаних наслідків [7-9]. Споживання йоду вважається таким, що перевищує потребу, а забезпеченість йодом такою, яка може створити незначний ризик надмірного споживання для населення, за медіани йодурії 200-299 мкг/л; $\geq 300$ мкг/л - споживання йоду є надмірним, існує небезпека негативних наслідків для здоров’я (йод-індукованого гіпертиреозу, 
автоімунних захворювань Щ3). У дітей шкільного віку концентрацію йоду в сечі $\geq 500$ мкг/л пов’язують зі збільшенням об'єму ЩЗ, що дає негативні наслідки хронічного надлишку йоду [2-4].

Більшість людей сприймають хронічне надмірне споживання йоду з їжею через гомеостатичний механізм, відомий як ефект Вольфа - Чайкова. У відповідь на значне навантаження йодом відбувається тимчасове пригнічення синтезу тиреоїдних гормонів. Після кількох днів постійного впливу високих рівнів йоду здатність уникнути наслідків гострого ефекту Вольфа - Чайкова обумовлено зменшенням активного транспорту йоду в Щ3, і синтез гормонів щитоподібною залозою поновлюється на нормальних рівнях.

Деякі пацієнти сприйнятливі до гострого ефекту Вольфа - Чайкова, що призводить до гіпотиреозу в умовах високого споживання йоду. Надто чутливим може бути плід, адже здатність уникати гострого ефекту Вольфа - Чайкова не формується повноцінно до 36-го тижня вагітності.

Допустимі верхні рівні споживання йоду визначено як такі, що, імовірно, не несуть ризику несприятливих наслідків для здоров'я майже для всіх людей у загальній популяції. Верхні рівні споживання грунтуються на загальному споживанні поживних речовин з їжі, води та добавок і застосовуються в постійному щоденному вживанні. Вплив надлишку йоду може призвести до високої поширеності дисфункції ЩЗ, збільшення частоти гіпертиреотропінемії та розвитку гіпертиреозу в новонароджених. Окрім того, йод-індукований гіпотиреоз було зареєстровано в дітей, які зазнали впливу надлишку йоду в ході рентгеноконтрастних досліджень:

- йодовані внутрішньовенні рентгенографічні контрастні агенти містять до 380 мг/мл йоду;

- аміодарон містить 75 мг йоду на 200 мг таблетки;

- деякі антисептики містять йод, хоча системна абсорбція зазвичай не має клінічно важливого значення в дорослих, за винятком пацієнтів із тяжкими опіками;

- йодовмісні протиастматичні препарати та відхаркувальні засоби, деякі харчові добавки, такі як водорості, і деякі препарати йоду можуть містити йод, кількість якого в кілька тисяч разів перевищує денну верхню межу;

- категорично забороняється використовувати для профілактики зоба краплі спиртового розчину йоду або розчину Люголя (в одній краплі розчину Люголя міститься йоду в 100 разів більше, ніж потрібно організму на день).

Слід визнати, що навіть низькі дози йоду можуть викликати автоімунні процеси в щитоподібній залозі в невеликої частини жінок [1].

ВООЗ регламентовано - під час вагітності добове споживання йоду $>500$ мкг може бути надмірним, винятком можуть бути популяції, що історично послідовно споживали понад 500 мкг на добу, не відчуваючи побічних ефектів (наприклад, Японія). Вживання йоду та добавок із бурих водоростей, що містять йод, понад 500 мкг/добу не рекомендується під час вагітності через можливий розвиток дисфункції ЩЗ у плода або грудного вигодовування, за винятком випадків підготовки до хірургічного лікування хвороби Грейвса.

Керівництво Американської тиреоїдної асоціації «Діагностика та лікування захворювань щитоподібної залози під час вагітності та в післяпологовий період» (2017) регламентує:

- оптимальними є препарати йоду у формі калію йодиду. Бурі водорості та інші форми морських водоростей не забезпечують послідовне щоденне адекватне вживання йоду через варіативність вмісту йоду в них;

- жінкам, які планують вагітність або вагітні, слід збагатити свій раціон щоденною оральною добавкою, що містить 150 мкг йоду у формі калію йодиду, стартувати оптимально за 3 місяці перед планованою вагітністю;

- у регіонах із вираженим дефіцитом йоду вузли Щ3 можуть бути присутніми в 30\% вагітних. Синтез гормонів в автономних вузлах ЩЗ залежить від доступної кількості йоду, тому жінки з таким захворюванням, ймовірно, мають утримуватися від приймання йодовмісних добавок під час вагітності, надто якщо вже використовується йодована сіль;

- жінки, які регулярно приймають левотироксин $\left(\mathrm{L}-\mathrm{T}_{4}\right)$, не мають потреби в додатковому вживанні йоду як субстрату для синтезу гормонів;

- не слід призначати препарати йоду вагітним, які лікуються від гіпертиреозу;

- у регіонах із дефіцитом йоду від легкого до помірного ступеня наразі не проведено досліджень, в яких би конкретно вивчався вплив добавок йоду в період лактації.

Рекомендації ВООЗ є такими: вживати йод у дозі 250 мкг/добу для вагітних і жінок, що годують груддю (цей рівень підтверджено резуль- 
татами обстеження понад 7000 вагітних китаянок, які встановили, що субклінічний гіпотиреоз і гіпотироксинемія траплялися рідше за йодурії 150-249 мкг/л, але ризик обох цих порушень підвищувався, коли показник йодурії був нижчим або вищим за цей діапазон). Інститут медицини США рекомендував як цільовий показник для індивідуального загального добового споживання йоду (харчування + доповнення до харчування) 220 мкг/добу для вагітних і 290 мкг/добу для жінок, які годують груддю, 150 мкг/добу для жінок, які планують вагітність. Промисловою групою США рекомендовано включати 150 мкг йоду в полівітамінні препарати для цих категорій жінок.

В Україні Інструкція Міністерства охорони здоров’я до препаратів йоду містить такі застереження [10]:

- Протипоказання: не дозволяється застосовувати за маніфестного гіпертиреозу; латентного гіпертиреозу в дозах, які перевищують 150 мкг йоду на добу; за наявності автономної аденоми та фокальних і дифузних осередків автономії ЩЗ у дозах від 300 мкг до 1000 мкг йоду на добу, за винятком передопераційної йодотерапії, з метою блокади ЩЗ за Пламером. Не можна цілком виключити, що за наявності в ЩЗ більш значних автономних ділянок і за добових доз понад 150 мкг йоду гіпертиреоз може перейти в маніфестну форму. У дорослих на тлі застосування препарату в дозах від 300 мкг до максимальної 1000 мкг йоду на добу в окремих випадках може розвинутися гіпертиреоз, індукований йодом. Передумовою цього в переважній більшості випадків є наявність у Щ3 дифузних або обмежених осередків автономії.

- Взаємодія з іншими лікарськими засобами. Дефіцит йоду підвищує, а надмір його знижує реакцію на терапію гіпертиреозу тиреостатичними засобами, у зв'язку із цим перед лікуванням або під час лікування гіпертиреозу необхідно уникати, якщо це можливо, будьякого приймання йоду. Тиреостатичні засоби, зі свого боку, гальмують перехід йоду в органічні сполуки в Щ3 і, отже, можуть спричиняти утворення зоба. Поглинання йоду ЩЗ конкурентно пригнічується речовинами, проникнення яких в орган відбувається за таким самим механізмом «захоплення», як і проникнення йоду, наприклад перхлоратом, а також субстанціями, які самі собою не транспортуються, наприклад тіоціанат, у концентрації, що перевищує 5 мг/дл. Поглинання йоду Щ3 і його обмін у ній стимулюються ендогенним та екзогенним ТТГ. Одночасне лікування високими дозами йоду, які пригнічують інкрецію гормонів Щ3, і солями літію може провокувати виникнення зоба та гіпотиреозу. Вищі дози калію йодиду в поєднанні з калій-зберігаючими діуретиками можуть призводити до гіперкаліємії.

- Особливості застосування. У зв'язку з проходженням йоду через плаценту та чутливістю плода до фармакологічно активних його доз, йод не рекомендують призначати в міліграмовому діапазоні. Це стосується також періоду лактації, оскільки концентрація йоду в молоці в 30 разів перевищує таку в сироватці крові. Винятком $\epsilon$, звичайно, високодозована йодна профілактика, яка проводиться після ядернотехнічних аварій.

Категорично забороняється використовувати для профілактики зоба краплі спиртового розчину йоду або розчину Люголя (в одній краплі розчину Люголя міститься йоду в 100 разів більше, ніж потрібно організму на день).

\section{Висновки}

1. Профілактику ЙдЗ регламентовано, стандартизовано актуальними міжнародними керівництвами, вона є доступною, ефективною, дозволяє запобігати розвитку наслідків йодного дефіциту (у тому числі тяжких, необоротних - розумової відсталості, кретинізму).

2. Призначати препарати йоду слід з урахуванням протипоказань, взаємодії з іншими лікарськими засобами, особливостей застосування. Необхідними є попередні як ультразвукове, так і лабораторне обстеження пацієнта щодо тиреоїдної патології. Оптимальний комплекс лабораторної оцінки тиреоїдного статусу включає визначення рівнів ТТГ, вільного тироксину (в $\left.\mathrm{T}_{4}\right)$, вільного трийодтироніну $\left(\right.$ в $\left._{3}\right)$, антитіл до тиреоїдної пероксидази (АТПО) та антитиреоїдних антитіл (АТТГ), за підозри на гіпертиреоз - визначення антитіл до рецептора ТТГ, за наявності додаткового утворення в ділянці Щ3 - визначення рівнів паратгормону, кальцію іонізованого, 25-гідроксивітаміну D, кальцитоніну. 
3. В інтерпретації отриманих результатів слід враховувати інтерферуючі чинники, що впливають на результати досліджень (супутні стани в пацієнта, приймання препаратів, дотримання пацієнтом умов преаналітичного етапу), у тому числі можливість отримання хибних результатів, якщо пацієнт приймає препарати біотину, а лабораторне дослідження проводилося за біотин-залежною методикою імуноаналізу.

На відміну від інших лабораторій, у МЛ «ДІЛА»:

- методики визначення ТТГ, в , $_{4}$ в , $_{3}$ АТПО, АТTГ, антитіл до рецептора ТТГ стимулюючих, паратгормону, 25-гідроксивітаміну D є біотин-незалежними;

- ТТГ, в $\mathrm{T}_{4}$ - наявні референси для вагітних;

- унікальна методика визначення антитіл до рецептора ТТГ стимулюючих - достовірна диференційна діагностика та моніторинг хвороби Грейвса.

МЛ «ДІЛА» - достовірна діагностика та моніторинг тиреоїдного статусу.

\section{Список використаної літератури}

1. Alexander EK, Pearce EN, Brent GA, Brown RS, Chen H, Dosiou C, et al. 2017 Guidelines of the American Thyroid Association for the diagnosis and management of thyroid disease during pregnancy and the postpartum. Thyroid. 2017 Mar;27(3):315-89.

2. UNICEF https://data.unicef.org/topic/nutrition/iodine-deficiency/ Iodine deficiency July 2018.

3. EQUIP Ensuring the Quality of Urinary Iodine Procedures, March 2012.

4. WHO Assessment of iodine deficiency disorders and monitoring their elimination: a guide for program managers. 3rd ed, 2007.

5. Скрипник НВ. Подолання йододефіциту - ключ до розвитку країни. Здоров'я України. 2016;1(33). (Skrypnyk NV. Overcoming iodine deficiency is the key to developing the country. Zdorov'ya Ukrayiny. 2016;1(33).

6. Кваченюк АМ, Кваченюк ДА. Клініко-лабораторні особливості застосування замісної тиреоїдної терапії в пацієнтів похилого віку. Міжнародний ендокринологічний журнал. 2018;14(3) 275-8. (Kvachenyuk AM, Kvachenyuk DA. Clinical and laboratory features of the use of thyroid replacement therapy in elderly patients. Mizhnarodnyy endokrynolohichnyy zhurnal. 2018;14(3): 275-8).

7. Bartalena L, Bogazzi F, Chiovato L, Hubalewska-Dydejczyk A, Links TP, Vanderpump M. 2018 European Thyroid Association (ETA) Guidelines for the management of amiodarone-associated thyroid dysfunction. Eur Thyroid J. 2018;7(2):55-66.

8. Haugen BR. 2015 American Thyroid Association management guidelines for adult patients with thyroid nodules and differentiated thyroid cancer: What is new and what has changed? Cancer. 2017;123:372-81.

9. Jonklaas J, Bianco AC, Bauer AJ, Burman KD, Cappola AR, Celi FS, et al. Guidelines for the treatment of hypothyroidism: prepared by the American Thyroid Association Task Force on thyroid hormone replacement. Thyroid 2014; 24(12). https://doi.org/10.1089/ thy. 2014.0028

10. L-тироксин 50 Берлін-Хемі. Інструкція, застосування препарату (L-thyroxine 50 Berlin-Hemi. Instruction, use of the drug) http:// mozdocs.kiev.ua/likiview.php?id=6732

(Надійшла до редакції29.08.2019p.)

\section{Актуальные диагностические решения клинической задачи «Оценка уровня йодного насыщения организма»}

\section{М.И. Бобрик, В.М. Резниченко}

${ }^{1}$ Национальный медицинский университет имени А.А. Богомольца ${ }^{2}$ Государственное учреждение «Поликлиника № 2» Государственного управления делами

Резюме. В статье приведены актуальные алгоритмы ведения пациентов с йододефицитом, в том числе оптимальный комплекс лабораторной оценки тиреоидного статуса перед назначением терапии - определения уровней ТТГ, св. Т (и св. Т) АТТГ), при подозрении на гипертиреоз - определение антител к рецептору ТТГ стимулирующих, при наличии дополнительного образования в области щитовидной железы - определение уровней паратгормона, кальция ионизированного, 25-гидроксивитамина D, кальцитонина. Обоснована необходимость учета интерферирующих факторов, влияющих на результаты исследований (сопутствующие состояния у пациента, прием препаратов, соблюдение пациентом условий преаналитического этапа), в том числе возможность получения ложных результатов, если пациент принимает препараты биотина и лабораторное исследование проводилось по биотин-зависимой методике иммуноанализа.

Ключевые слова: йододефицит, ТТГ, св. Т АТ цептору ТTГ стимулирующие, 25-гидроксивитамин D, кальцитонин, интерферирующие факторы, биотин.

\section{Current diagnostic solutions of the clinical problem «Assessment of the level of body iodine saturation»}

\section{Bobryk, V. Reznichenko \\ ${ }^{1}$ Bogomolets national medical university \\ ${ }^{2}$ State Institution «Polyclinic № 2» of the State Affairs Department}

\begin{abstract}
Current algorithms for managing patients with iodine deficiency are presented in the article, including the optimal complex of laboratory evaluation of thyroid status before prescribing therapy determination of TSH, free $\mathrm{T}_{4}$ (and free $\mathrm{T}_{3}$ ), ATPO (and ATTG), in case of suspected hyperthyroidism - determination of TSH receptor stimulating antibodies. In case of nodular goiter, determination of parathormone levels, calcium lonized, 25-hydroxyvitamin D is recommended. The necessity to take into account the interfering factors that influence the laboratory results (concomitant conditions in the patient, medication, adherence of the patient to the preanalytic stage), including the possibility of obtaining false results if the patient takes biotin and laboratory tests are biotin-dependent
\end{abstract}

Keywords: iodine deficiency, TSH, free $\mathrm{T}_{4^{\prime}}$ ATPO, TSH receptor stimulating antibodies, 25-hydroxyvitamin D, interfering factors, biotin. 